University of Nebraska - Lincoln

DigitalCommons@University of Nebraska - Lincoln

2019

\title{
WHAT IS THE USE VALUE OF IRRIGATION WATER FROM THE HIGH PLAINS AQUIFER?
}

\author{
Federico García Suárez \\ Universidad de la Republica, Uruguay, fgarcia@fagro.edu.uy \\ Lilyan E. Fulginiti \\ University of Nebraska-Lincoln, Ifulginiti1@unl.edu \\ Richard K. Perrin \\ University of Nebraska-Lincoln, rperrin@unl.edu
}

Follow this and additional works at: https://digitalcommons.unl.edu/ageconfacpub

Part of the Agricultural and Resource Economics Commons

García Suárez, Federico; Fulginiti, Lilyan E.; and Perrin, Richard K., "WHAT IS THE USE VALUE OF IRRIGATION WATER FROM THE HIGH PLAINS AQUIFER?" (2019). Faculty Publications: Agricultural Economics. 164.

https://digitalcommons.unl.edu/ageconfacpub/164

This Article is brought to you for free and open access by the Agricultural Economics Department at DigitalCommons@University of Nebraska - Lincoln. It has been accepted for inclusion in Faculty Publications: Agricultural Economics by an authorized administrator of DigitalCommons@University of Nebraska - Lincoln. 


\section{What is the use value of irrigation water from the High Plains Aquifer?}

This study provides an estimate of the gross value of irrigation water from the U.S. High Plains Aquifer. We estimate a yield function for aggregated crop biomass production, based on county-level observations for 1960-2007. This study found that irrigation increases total biomass yield in this region by an average of $51 \%$. We estimate the average gross annual value of irrigation as of 2007 to be $\$ 196$ per acre, for a total of about $\$ 3$ billion across the aquifer. We also estimate that on average across the aquifer, exposure to 24 hours of temperatures above $33^{\circ} \mathrm{C}$ (one degree day) reduces biomass yield by $3 \%$, with a value in 2007 of about $\$ 10$ per acre.

Keywords: groundwater, High Plains Aquifer, irrigation response, production function, yields.

JEL codes: Q15, Q32

Federico García Suárez, Assistant Professor, Universidad de la Republica, Uruguay

Lilyan E. Fulginiti, Frederick Professor, University of Nebraska, Lincoln, U.S.

Richard K. Perrin, Roberts Professor, University of Nebraska, Lincoln, U.S.

Support is acknowledged from the Daugherty Water for Food Global Institute at the University of Nebraska and from the Nebraska Agricultural Experiment Station with funding from Hatch Multistate Research capacity funding program (Accession numbers NEB 1011054 and NEB 227784) from USDA National Institute of Food and Agriculture. 
Since the mid-20th century, agricultural production in the Great Plains region of the U.S. has increased rapidly due to increases in irrigation, with most of the water being drawn from the High Plains Aquifer (HPA). The HPA underlies an area that includes southern South Dakota, southeast Wyoming, eastern Colorado, Nebraska, western Kansas, eastern New Mexico, northwest Oklahoma, and northwest Texas. This region has a semiarid climate that makes crop production highly dependent on irrigation. Given that irrigation has resulted in varying levels of depletion of the HPA (Scanlon, et al., 2012), it is important for policy purposes to identify the overall value of this resource in agricultural production.

In this study we estimate the total gross value added by irrigation to agricultural production in the 205 counties over the HPA, based on historical yields, prices and acreage irrigated.

\section{Literature Review}

The research here estimates the extra production of agricultural biomass attributable to irrigation at the county level, and values that at the county average biomass price, to obtain estimates of the additional revenue flow attributable to irrigation. In a generally similar approach, Peterson and Ding (2005), examined the effect of incentives for water-efficient irrigation systems in Kansas, using an estimated field-level production function with data from a crop simulator. They combined this with budgeted costs to infer that the extra net return for irrigation was about $\$ 77$ per acre for flood or pivot irrigation in the early 2000's. Using the Water Optimizer decision aid, Savage and Brozović (2009) estimated, for each of 35,502 wells across Nebraska, the revenue 
impacts of switching to irrigated production for every year from 1960-2005, using current prices. (They then predict the year of adoption using the current estimate of gain in net revenue from switching to irrigated corn versus rainfed wheat.) Relevant to our study, they estimate the average additional revenue from adopting irrigation to be $\$ 234$ per acre.

An alternative approach to measuring the value of irrigation is to compare sales values of land over the aquifer versus land not over the aquifer. The first study of this type across the HPA was that by Torell, Libbin and Miller. (1990), who examined sales data, 1979-86, for 7,298 sales of irrigated and non-irrigated parcels in five states over the HPA. The simple difference in average sale value was $\$ 255$ per acre, though they went on to calculate implied values of the aquifer water itself (averaging $\$ 3.93$ per acre foot stored). The next study in the HPA using market values was that of Brozović and Islam (2010), who examined 330 land sales between 2000 and 2008 just in Chase County, Nebraska. Regression analysis indicated a premium of $\$ 712-723$ per acre for sales value of irrigated land over non-irrigated, while a propensity score matching analysis indicated a premium of $\$ 839$ per acre. There have been no other such studies based on sale values, but Hornbeck and Keskin (2014) examined average values of agricultural land reported at the county level across the entire HPA and counties within $100 \mathrm{~km}$ of it, from 1920-2002. They estimated that land over the HPA (also known as the Ogallala) had a value premium of $\$ 90$ per acre in $1950, \$ 243$ per acre in 1978 , falling to around $\$ 100$ per acre in 2002 (exact figures for the latter were not reported).

Studies using the value of production approach to estimating HPA irrigation value thus provide estimates of \$234 per acre across Nebraska 1960-2005 (Savage and Brozović, 2009), and \$77 per acre in Kansas in the early 2000's (Peterson and Ding, 
2005). Studies using the land sales value approach provide estimates of the premium for the market value of irrigated land averaging $\$ 243$ per acre in 1978 to about $\$ 100$ in 2002 (Hornbeck and Keskin, 2014), \$255 per acre across five states during 1979-1986 (Torell, Libbin and Miller, 1990), and \$712-723 in Chase Co, NE, 2000-2008 (Brozović and Islam, 2010).

The three studies of land sales value premia are relatively consistent, except for the very low values for 2002 by Hornbeck and Keskin (2014). The two value of production approaches offer dramatically different values, of which only the $\$ 77$ per acre estimate is plausibly consistent with the estimates of sales value. To help resolve these discrepancies, in this study we estimate the effect of irrigation on the gross value of production at the county level across the entire HPA, using a production function approach with published survey data from USDA-NASS over the period 1960-2007. ${ }^{\mathrm{i}}$

\section{Conceptual Approach and Model}

Our approach to measuring the value of irrigation from the HPA is to estimate increased biomass production due to irrigation by means of a county-level biomass yield function that has as one of its arguments the fraction of crop land irrigated. Our estimate of increased output due to irrigation is obtained by differentiation of this function with respect to fraction irrigated. We multiply this production increase by average biomass price in that county to provide our estimate of the gross value of irrigation for that county and year.

We measure biomass output as the aggregate of all crop biomass produced in a county (both harvested crop and unharvested residual), expressed in tons of dry matter 
produced per acre, which is an approximation to net primary production. The aggegation across crops is driven mainly by the fact that we do not have county-level data on the acreage irrigated for some crops, while we do have data on total acres irrigated and total production for all crops. We aggregate harvested and unharvested portions of the crop to provide a closer approximation to net primary agricultural production, the true biomass response to weather and management efforts.

Estimation of production functions can be enhanced by simultaneously estimating share equations that reflect producers' evaluation of marginal product of inputs. The profit maximizing decisions of price-taking crop producers can be represented as

$$
\max _{\boldsymbol{x}} \pi=p y-\boldsymbol{w}^{\prime} \boldsymbol{x} ; y=f(\boldsymbol{x}, \mathbf{z}, t) ; p>0, \boldsymbol{w} \gg 0
$$

where $\boldsymbol{x}$ is a vector of variable inputs, $y$ is yield (metric tons of biomass produced per acre), the corresponding price vectors are $\boldsymbol{w}$ and $p, \boldsymbol{z}$ is a vector of environmental characteristics and $t$ is time measured in years, a proxy for technical change. The production function $y=f(\boldsymbol{x}, \boldsymbol{z}, t)$ is assumed to be monotone and quasi-concave in inputs and the input requirement set must be closed and bounded. Given that the function is differentiable, the first order conditions for maximization of profit (1) are

$$
\frac{\partial \pi}{\partial x_{k}}=p \cdot \frac{\partial f(x, z, t)}{\partial x_{k}}-w_{k}=0, k=1, \ldots, K .
$$

Expressing equations (1) and (2) in logarithms, we obtain production elasticities $\epsilon_{k}$ that also reflect the share of factor payments in output value, $s_{k}$, as:

$$
\epsilon_{k}(\boldsymbol{x}, \mathbf{z}, t) \equiv \frac{\partial \ln f(\boldsymbol{x}, \boldsymbol{z}, t)}{\partial \ln x_{k}}=\frac{w_{k}}{p} \cdot \frac{x_{k}}{y}=s_{k}(\boldsymbol{x}, \mathbf{z}, t), k=1, \ldots, K
$$


We specify the yield function as:

$$
\ln y=\alpha+\boldsymbol{\beta}^{\prime} \boldsymbol{v}+\boldsymbol{v}^{\prime} \boldsymbol{B} \boldsymbol{v}+\boldsymbol{\delta}^{\prime} \boldsymbol{d},
$$

where $y$ is biomass output per acre, $\boldsymbol{v}=(\boldsymbol{l n} \boldsymbol{x}, i, r, t)^{\prime}, \boldsymbol{d}=(\boldsymbol{\operatorname { l n } D \boldsymbol { D }})$, and $\alpha, \boldsymbol{\beta}, \boldsymbol{\delta}$ and $\boldsymbol{B}$ are parameters to be estimated. The vector $\boldsymbol{x}$ consists of indexes of fertilizer and chemicals applied, $i$ is the fraction of planted land that is irrigated, $r$ is precipitation in inches, and $\boldsymbol{D D}$ is a vector of degree-days variables (the total length of time, in days, that the crops were exposed to temperatures in a specific range).

From equation (3) the input production elasticities vector $\epsilon$ is

$$
\epsilon=\beta+B^{\prime} v=s
$$

These elasticities indicate the percentage change in biomass output per one percent change in each of the inputs. The variables $i, r$, and $t$, however, are measured in levels, rather than logarithms of levels. In these cases, the derivative of $\ln y$ with respect to $x$ represents semi-elasticity of response, which is intrerpreted as the percentage change in biomass yield per unit change in $x$ (i.e., per change from $\mathrm{i}=0$ to $\mathrm{i}=1$, per inch of precipitation, and per year of time).

We use the semi-elasticity with respect to irrigation, $\epsilon_{i}$, to estimate the increase in yield due to irrigation. The increase in gross value per acre, $V$, we calculate as the product of the irrigation semi-elasticity times yield to estimate increased production, then times the price of biomass, as

$$
V_{j t}=\epsilon_{i j t} y_{j t} p_{j t}
$$

where $V_{j t}$ indicates gross value of irrigation in county $j$ and period $t,\left(\epsilon_{i j t} y_{j t}\right)$ is the corresponding estimate of increased biomass production due to irrigation, and $p_{j t}$ is the average price received for biomass produced in that county and year. The value of 
irrigation is thus reflected in both the higher production and any higher price for that production if producers are producing more valuable crops on the irrigated acreage.

\section{Data}

This study considers $205^{\text {ii }}$ counties which lie in part or in whole over the High Plains aquifer in the states of South Dakota, Wyoming, Nebraska, Kansas, Oklahoma, and Texas. Basic crop production and acreage data during the years 1960-2007 are from the surveys conducted by the National Agricultural Statistics Service of the U.S. Department of Agriculture (NASS, USDA). Output $y$ is total biomass yield in tons of dry matter per acre. It consists of the aggregate of all above-ground biomass produced by all crops in the county ${ }^{\text {iiii }}$, divided by total acres planted, giving us net primary production. Biomass yield for county $j$ in year $t$ is calculated as

$$
y_{j, t}=\left\{\sum_{c} \frac{\text { Production }_{j, c, t}}{\text { Harvest Index }_{c}}\left[\text { Dry Matter }_{c}\right]\right\} / \text { Acres }_{j, t}
$$

where $c$ indexes crops. Production is the county-wide harvest for crop $c$ as reported by NASS, expressed in tons. Harvest index is the proportion of the above-ground biomass of crop $c$ that is harvested. Dry matter indicates the dry matter fraction of the harvest for crop $c$, and Acres is total acres planted in the county.

The nominal biomass price for each observation is calculated by dividing the value of total production of all crops by the total biomass produced. This nominal price was then adjusted to 2007 dollars using the CPI index to provide a real price:

$$
p_{j t}=\left(\mathrm{CPI}_{t}^{2007}\right)\left\{\sum_{c} \frac{\left(p_{j, c, t}\right)\left(\text { Production }_{j, c, t,}\right)}{\text { Harvest Index }_{c}}\left[\text { Dry Matter }_{c}\right]\right\}
$$


where $p_{j c t}$ is the reported price for crop $c$ in county $j$, year $t$ and $p_{j t}$ is the average biomass price in county $j$, expressed in 2007 dollars. Note that this price is an average value of non-harvested and harvested biomass.

Annual data on agricultural inputs are generally not available at the county level. The Agricultural Census provides county-level expenditures on fertilizer and chemicals approximately every five years. We first converted expenditures for each county into quantity indexes by dividing by a national price index ${ }^{\mathrm{iv}}$. Linear interpolation of this index was used between census years. We then divided each of these values by the values for Adams county, Nebraska, in 1960, to provide the final quantity indexes for fertilizer and chemical inputs. Because county-level expenditures on fertilizers and chemicals were first reported in 1964, we used state-level changes from 1960-64 (from USDA, ERS) to estimate county data for 1960-64.

We measure irrigation, $i$, as the ratio of irrigated area (all crops) to total planted cropland (figure 1). Irrigated area is irrigated acres planted in most cases. When both irrigated acres planted and the number of irrigated acres harvested were reported, we use the larger. In some cases we used irrigated acres harvested because that was the only figure reported. Different irrigation technologies (flood, center pivot, etc.) achieve different irrigation efficiencies, which would result in different relationships between a given amount of water applied and yield enhancement. We do not have data on the mix of such technologies used by county and year, so the differences in irrigation impact we estimate for each county and year will in part reflect differences in irrigation technologies used. 
Weather variables included are precipitation and temperature. Daily precipitation by county was constructed as a distance-weighted average of precipitation at the five weather stations closest to the county center (Trindade, 2011). Our precipitation variable consists of the sum of these values from March through August. Following Schlenker and Roberts (2009) we calculate temperature variables as the amount of time during March through August that the crops were exposed to temperatures in specific ranges. To construct these variables, we first calculated daily high and low temperatures for each county as the average of the five stations mentioned above. The number of hours within each temperature range during that day was then estimated using the sine curve method of Snyder (1985) and explained in detail in Trindade (2011). The number of hours each day in each range was added for the months of March through August, then divided by 24 to obtain the degree-day variables. We constructed four such degree-day variables, the number of days with temperatures between -5 to $8^{\circ} \mathrm{C}, D D(-5$ to 8$) ; 8$ to $15^{\circ} \mathrm{C}, D D(8$ to 15); 15 to $33^{\circ} \mathrm{C}, D D(15$ to 33$)$; and $33+{ }^{\circ} \mathrm{C}, D D(33+)$. Table 1 presents summary statistics of these variables.

\section{Results}

After adding error terms and imposing symmetry in the second order parameters, the production function in (4) and the share equations (5) for fertilizers and chemicals were simultaneously estimated using three alternative econometric models: seemingly unrelated regression with fixed effects (SUR+FE), three stage least squares (3SLS), and 3SLS with fixed effects (3SLS+FE). Using the three different models allows us to 
explore the implications of potential endogeneity and cross sectional variation not captured by the variables included in the analysis. Because yield and the input variables are on a per acre basis, to account for the relative size of each county we used weighted regression with the county share of regional biomass production each year as weights. Because of the potential for bias due to endogeneity, in the 3SLS implementations we instrumented fertilizer, chemicals, and irrigation using prices and lagged values of each input, and expected output prices ${ }^{\mathrm{v}}$ as instruments.

Parameter estimates and standard errors from the three econometric models are shown in the supplementary material Appendix 1, table 1 . Table 2 summarizes results in terms of production elasticities (equation 3) for fertilizer, chemicals, and precipitation, and semi elasticities (percentage change in output per unit change of variable) for irrigation, degree days and time as a proxy for technical change.

We found that the SUR+FE and 3SLS+FE models had the lowest Akaike Information Criterion (AIC). But the SUR+FE estimates violated the monotonicity property of the production function and therefore are inconsistent with decisions guided by profit maximizing behavior. Balancing statistical fit and economic properties leads to the choice of the 3SLS+FE model to use in further analysis. Parameter estimates and first-stage regressions and statistics are available in the online supplementary material ${ }^{\mathrm{vi}}$. We estimated 229 parameters (204 county effects and 25 parameters for equation (4), twelve of which are shared with equations (5)) with 9840 observations. 196 parameters are significant at $1 \%, 5$ at $5 \%$ and 4 at $10 \%$. The simpler Cobb-Douglas form was tested for and rejected. Given the panel nature of the data set, a Breusch-Pagan Lagrange Multiplier test was performed, which indicated that estimation of county effects is 
appropriate. A Hausman test led to the choice of fixed effects over random effects. A Wald test indicated heteroscedasticity, so robust errors were calculated using White's approach.

The average irrigation (IR) semi-elasticity (equation 5) across all counties and years is 0.511 (table 2), indicating that changing an acre from dryland to irrigated increases yield by approximately 51\% (95\% confidence interval of $39.3 \%$ to $62.9 \%)^{\mathrm{vii}}$. This estimate changes through time and across counties. In particular it is interesting to note the negative coefficient for irrigation squared. This implies that the yield boost from irrigation declines as the fraction of irrigated land increases within a county, presumably due to decreasing quality of land within a county. Figure 2 shows the evolution of these semi-elasticity estimates through time by state. The irrigation responses tend to be stable through the mid-1970s, increasing thereafter (Texas data before 1972 were not available.) Elasticities in Wyoming show a drop at the end of the period (2006 and 2007) that corresponds to a dramatic percentage increase on a small base of irrigated land, as shown in figure 1. Counties in South Dakota show the highest irrigation elasticities, reflecting the small share of the land irrigated. Clearly, since the response to irrigation depends on several variables, there is no single factor that explains the differences across states or across time.

The annual increment in biomass produced due to irrigation, and the value of that increment per acre irrigated (equation 6), are summarized by state in columns 4 and 6 of table 3. The production increase averaged slightly over one metric ton per acre across all years and counties. The incremental values averaged $\$ 125.2$ per acre. The lowest state average, $\$ 85.74$ for Texas, is low because some of those counties showed quite low 
yields. Multiplying these values times the number of acres irrigated provides an estimate of the average annual total gross value of irrigation across the entire HPA, about $\$ 1.5$ billion per year (in 2007 dollars). Table 4 presents similar values calculated for 2007, which had grown to a production increment of 1.9 tons per acre, $\$ 196$ per acre irrigated with a total value of $\$ 3$ billion that year. Figure 3 shows the evolution of the estimated annual average irrigation water value per acre by state expressed in 2007 dollars. The map in figure 4 illustrates these estimates by county in 2007.

We emphasize that these are estimates of additional revenue per acre. We do not have sources to estimate the additional costs of irrigated production by county. However, on the basis of a number of publications over the past 35 years, it appears that average irrigation costs in the plains were in the vicinity of $\$ 50$ per acre in the middle decade of our data (relative to gross benefits of $\$ 58$ ), but in the vicinity of $\$ 80-90$ per acre in the final decade (relative to benefits of $\$ 100$ or more). It is reasonable to guess that irrigation costs were sufficiently low to yield realized net benefits of at least $\$ 10-15$ per acre across counties and years.

Are our estimates plausible, given results of other studies? The closest studies in approach are those of Peterson and Ding (2005) and Savage and Brozović (2009), who used crop simulators to estimate extra production and thus extra revenue from irrigation at given sites. The former examined fields in western Kansas for which they estimated an additional $\$ 77$ net returns per acre, which would correspond to approximately an additional $\$ 175$ gross revenue per acre comparing to our estimate of $\$ 136.48$ for Kansas over 1960-2009. Savage and Brozović (2009) simulated switching from non-irrigated to irrigated production at every well in Nebraska, 1960-2005, with an average estimate of 
\$234 more in gross revenue per acre from irrigation, compared to our average estimate of $\$ 142.94$ for Nebraska. Both of these simulation studies suggest higher returns than we estimate. The simulation algorithms reflect beliefs by agronomists and others as to what factors determine yields, and those beliefs may be, on average, too optimistic about the impact of irrigation, but we have no convenient way to test that hypothesis other than comparison with our results.

The second kind of study offering evaluation of the plausibility of our resuts considers extra revenue per acre from irrigated land in the region. USDA data for 2007 showed that irrigated land in the region rented for about $\$ 55$ per acre more than nonirrigated land. When we add to that our crude estimate of $\$ 100$ of additional expenses, the corresponding gross revenue would have been about $\$ 155$ per acre more from irrigated land, compared to our estimate of the average for 2007 of $\$ 195.78$ per acre. Hornbeck and Keskin (2014) ran hedonic regressions of reported revenues per acre by county on the fraction of irrigated land and the proportion of land over the HPA, using 1920-2002 census data for 368 counties over and surrounding the HPA. Their results (their Table 4) indicated that irrigated land rented for 63\% more during 1950-74 (about $\$ 9 / a c$ ), and $114 \%$ (about $\$ 45 / a c$ ) more during 1978-2002. If extra costs for irrigated production were $\$ 100 / \mathrm{ac}$ or more in the latter period, their estimate of gross revenue from irrigation would have been about $\$ 150 /$ ac or more compared to our estimate of $\$ 195.78$ for 2007. While the Hornbeck-Keskin methodology is complex, and is based on census reports for a different set of counties, it appears that our estimate of added gross revenue from irrigation is higher than reported/calculated rental rate differentials would imply. 
Finally as previously noted, there have been three published studies of the premium in land value of irrigated versus non-irrigated land over the HPA. The relative ratio of irrigated to non-irrigated land value should be somewhat comparable to the ratio of net revenues. We would need relevant capitalization rates to convert these land values to annual flows directly comparable to our estimates, which is somewhat problematic due to the large variation of interest rates in the 1970s and 1980s, and furthermore the limited time horizon of water availability in some areas would very likely affect the apparent capitalization rates. Nontheless, the value premium estimated by Torell, Libbin and Miller (1990) for HPA parcel sales in 1979 was \$580, declining to \$329 in 1986, which averaged out to be a $45-50 \%$ premium, which compares well with our estimate of $51 \%$ increase in revenue, but higher than what our estimate of net revenue premium would be if we could correct for extra costs of irrigation. Brozović and Islam (2010) found a market premium of $\$ 700-800$ for irrigated land (60-70\% of the average parcel value), in Chase county parcel sales over several years. Our 2007 estimate of increased production (and thus of gross revenue) for that county is only $45 \%$, or about $\$ 270$ per acre. Finally, the Hornbeck-Keskin study analyzed census values of land per acre using the same approach as for revenue per acre. They estimated the premium for value of irrigated land over non-irrigated to be $41 \%$ during $1950-74$, declining to $26 \%$ during $1978-2002$, compared to our estimates of production increase averageing about 47\% during 1960-76 and about $54 \%$ later. Our estimates of the impact of irrigation are similar to HornbeckKeskin in the early years, but higher than theirs in later years. 
Summarizing, our estimates of the impact of irrigation are smaller than those suggested by crop simulation studies, larger than studies based on rental rates would imply, and mostly smaller than land value studies would imply.

Our analysis also has implications for the effects of weather on biomass yields. The degree-days coefficients in table 2 showthat temperatures above the $33^{\circ} \mathrm{C}$ threshold decrease yield by an average of about 3\% per degree day ( 24 hours of exposure to this

temperature). This finding is in line with that of Schlenker and Roberts (2009, figure A3) who found yield decreases of about $4 \%$ per degree day above $33^{\circ} \mathrm{C}$ for corn, for soybean and for cotton east of the $100^{\text {th }}$ meridian (an area mostly east of the HPA). Lambert (2014) also found a threshold for yield effects in Kansas for degree days above $32.2^{\circ} \mathrm{C}$. Our estimate of the average damage from 24 hours of temperatures above $33^{\circ} \mathrm{C}$ as of 2007 is about $\$ 10$ per acre (using the 2007 average yield of 3.34 tons of biomass per acre, valued at the average $\$ 104.26$ per ton).

\section{Conclusions}

The High Plains Aquifer (HPA) has been providing water for agricultural production for more than 50 years. In most counties the area under irrigation increased over this period. In this paper we estimate the value of irrigation using water from the HPA, in terms of the additional gross value of crops produced.

Using county-level data on total above-ground bone-dry biomass production by all crops over the period 1960-2007, we find that irrigation increased biomass yield by an HPA-wide average of $51 \%$. The average gross value of this increment in biomass we estimate at $\$ 125$ per acre per year (in 2007 dollars). Individual county values are highly 
variable, ranging from $\$ 26$ to $\$ 282$ per acre. By 2007 , the average yield increment had advanced to $60 \%$, and the average gross value to $\$ 196$ per acre, totaling about $\$ 3$ billion per year of additional revenue across the aquifer. The size of this income stream attests to the importance of research and policies related to its sustainability.

Our estimates of the average impact of irrigation from the HPA are somewhat smaller than those of other studies based on crop simulation models and based on land value premiums for irrigated land, but somewhat larger than those based on rental rate premiums.

It is important to note that the impact of irrigation on yields decreases as the portion of land irrigated within a county increases, presumably due to decreases in the quality of land within a county. Therefore one might expect that additional irrigation across the region would result in smaller yield increments that the average we estimate for 2007.

Of interest, too, is our estimate of potential crop losses due to high temperatures. We find that every 24 hours (one degree day) that crops are exposed to temperatures above $33^{\circ} \mathrm{C}$ reduces biomass yield by about $3 \%$, with a 2007 value of $\$ 10$ per acre lost.

The value of irrigation that we estimate is the value of additional biomass produced when land is irrigated relative to unirrigated land. It would be useful to measure value per acre-foot of water applied, but measures of water pumped per acre irrigated are available only for a few counties in some years. The extra costs of irrigated versus non-irrigated production need to be deducted from the values we estimate to obtain net value of irrigation, which we have not done because of lack of data on these values by county and year. 


\section{References}

Brozović, N. and S. Islam (2010, July). Estimating the value of groundwater in irrigation. In Agricultural and Applied Economics Association Annual Meeting, Denver, Colorado, pp. 34.

Ding, Y. and J. M. Peterson (2012). Comparing the cost-effectiveness of water conservation policies in a depleting aquifer: a dynamic analysis of the Kansas High Plains. Journal of Agricultural and Applied Economics 44, 223-234.

García Suárez, F. (2013). "Essays On The Economic Value Of The High Plains Aquifer.” PhD Dissertation, University of Nebraska Lincoln.

Hendricks, N. P. and J. M. Peterson (2012). Fixed effects estimation of the intensive and extensive margins of irrigation water demand. Journal of Agricultural and Resource Economics 37, 1-19.

Hornbeck, R., and P. Keskin (2014). The historically evolving impact of the Ogallala Aquifer: agricultural adaptation to groundwater and drought. American Economic Journal: Applied Economics 6 (1), 190-219.

Klein, Robert (2009). Nebraska Crop Budgets, 2009. EC872. U. of Nebraska Extension Service, Lincoln, Nebraska. Current edition accessible at http://cropwatch.unl.edu/budgets.

Lambert, D. K. (2014). Historical Impacts of Precipitation and Temperature on Farm Production in Kansas. Journal of Agricultural and Applied Economics 46 (4), 439-456. 
Mieno, T. and Brozović, N. (2016). Price elasticity of groundwater demand: Attenuation and amplification bias due to incomplete information, American Journal of Agricultural Economics 99 (2), 401-426.

Palazzo, A. and N. Brozović (2014). The role of groundwater trading in spatial water management. Agricultural Water Management 145, 50-60.

Peterson, J. M. and Y. Ding (2005). Economic adjustments to groundwater depletion in the High Plains: do water-saving irrigation systems save water? American Journal of Agricultural Economics 87, 147-159.

Pfeiffer, L. and C.-Y. C. Lin (2012). Groundwater pumping and spatial externalities in agriculture. Journal of Environmental Economics and Management 64, 16-30.

Pfeiffer, L. and C.-Y. C. Lin (2014a). Does efficient irrigation technology lead to reduced groundwater extraction? Empirical evidence. Journal of Environmental Economics and Management 67, 189-208.

Pfeiffer, L. and C.-Y. C. Lin (2014b). The Effects of Energy Prices on Agricultural Groundwater Extraction from the High Plains Aquifer. American Journal of Agricultural Economics 96, 1349-1362.

Savage, J. and N. Brozović (2009). Irrigation Technology Adoption Under Factor Price Uncertainty: Groundwater-Irrigated Production in Nebraska, 1960-2005. Paper presented at AAEA \& ACCI Joint Annual Meeting, Milwaukee WI, 26-28 July.

Scanlon, B. R., C. C. Faunt, L. Longuevergne, R. C. Reedy, W. M. Alley, V. L. McGuire, and P. B. McMahon (2012). Groundwater depletion and sustainability of irrigation in the U.S. High Plains and Central Valley. PNAS, vol.109 (24), $249320-9325$. 
Schlenker, W. and M. J. Roberts (2009). Nonlinear temperature effects indicate severe damages to U.S. crop yields under climate change. PNAS 106 (37), 15594-15598.

Snyder, R.L. 1985. "Hand calculating degree-days." Agricultural \& Forest Meteorology, $35(1), 353-358$.

StataCorp (2011). Stata Statistical Software: Release 12. College Station, TX.

Torell, L. A., J. D. Libbin, and M. D. Miller (1990). The market value of water in the Ogallala Aquifer. Land Economics 66, 163-175.

Trindade, F. J. (2011). Climate impact on agricultural efficiency: Analysis on counties in Nebraska along the 41st parallel. In Poster. Agricultural and Applied Economics Association Annual Meeting, July 24-26, 2011, Pittsburgh, Pennsylvania.

USDA, ERS. Agricultural Productivity in the U.S. accessed at: http://www.ers.usda.gov/data-products/agricultural-productivity-in-the-us.aspx.

USDA, NASS. QuickStats, accessed at: https://quickstats.nass.usda.gov/.

Young, R. A. and J. B. Loomis (2014). Determining the Economic Value of Water. New York, NY: RFF Press and Routledge.

Ziolkowska, J. R. (2015). Shadow price of water for irrigation - A case of the High Plains. Agricultural Water Management 153, 20-31. 
Tables

Table 1. Summary Statistics, 205 HPA Counties, 1960-2007

\begin{tabular}{lccccc}
\hline Variable & Units & Mean & Min & Max & Std. Dev. \\
\hline Biomass $(y)$ & metric tons per acre & 2.14 & 0.05 & 7.15 & 1.27 \\
Real Price $(p)$ & 2007 dollars per metric ton & 121.8 & 34.3 & 384.6 & 51.50 \\
Fertilizer $(x)$ & metric tons per acre & 0.13 & 0 & 1.428 & 0.08 \\
Chemicals $(x)$ & metric tons per acre & 0.07 & 0 & 2.025 & 0.05 \\
Irrigation $(i)$ & fraction & 0.24 & 0 & 0.94 & 0.22 \\
Precipitation & inches & 14.68 & 0.08 & 39.2 & 4.86 \\
DD $(-5$ to 8$)$ & 24 hours & 35.26 & 5.99 & 75.64 & 10.29 \\
DD(8 to 15) & 24 hours & 36.36 & 17.57 & 68.75 & 6.43 \\
DD $(15$ to33) & 24 hours & 105.85 & 38.66 & 150.46 & 15.45 \\
DDays $(33+)$ & 24 hours & 2.74 & 0 & 26.65 & 2.16 \\
\hline
\end{tabular}


Table 2. Average Elasticities for Translog Specifications, HPA Counties, 1960-2007

\begin{tabular}{llll}
\hline Elasticities & SUR+FE & 3SLS & 3SLS+FE \\
\hline Fertilizer & $0.209^{* * *}$ & $0.294^{* * *}$ & $0.262^{* * *}$ \\
& $(0.006)$ & $(0.006)$ & $(0.007)$ \\
\hline Chemicals & $0.112^{* * *}$ & $0.131^{* * *}$ & $0.062^{* * *}$ \\
& $(0.007)$ & $(0.007)$ & $(0.008)$ \\
\hline Precipitation $^{*}$ & $0.114^{* * *}$ & $0.240^{* * *}$ & $0.116^{* * *}$ \\
& $(0.008)$ & $(0.009)$ & $(0.008)$ \\
\hline Irrigation $^{\#}$ & $0.549^{* * *}$ & $0.410^{* * *}$ & $0.511^{* * *}$ \\
& $(0.046)$ & $(0.043)$ & $(0.060)$ \\
Time $^{\#}$ & $0.002^{* * *}$ & $2.3 \times 10^{-6}$ & $0.004^{* * *}$ \\
& $(0.0004)$ & $(0.0004)$ & $(0.0004)$
\end{tabular}

\begin{tabular}{llll}
\hline Coefficients & \multicolumn{3}{l}{} \\
\hline DD-5 to 8 & $0.304^{* * *}$ & $0.565^{* * *}$ & $0.454^{* * *}$ \\
& $(0.020)$ & $(0.022)$ & $(0.022)$ \\
\hline DD8 to 15 & $0.153^{* * *}$ & $0.157^{* * *}$ & $0.198^{* * *}$ \\
& $(0.020)$ & $(0.024)$ & $(0.022)$ \\
\hline DD15 to 33 & $0.686^{* * *}$ & $0.654^{* * *}$ & $0.959^{* * *}$ \\
& $(0.055)$ & $(0.053)$ & $(0.061)$ \\
\hline DD33+ & $-0.028^{* * *}$ & $-0.014^{* * *}$ & $-0.030^{* * *}$ \\
& $(0.002)$ & $(0.003)$ & $(0.003)$ \\
\hline AIC & -77797 & -72447 & -76225
\end{tabular}

Note: $* * *, * * *$ significant at the $10 \%, 5 \%$ and $1 \%$ level or better respectively, \# indicates semi-elasticity, $\mathrm{dlny} / \mathrm{dx}$. 
Table 3. Estimated Average Annual Irrigation Water Value by State (3SLS+FE), 1960-2007

\begin{tabular}{|c|c|c|c|c|c|c|c|}
\hline & $\begin{array}{c}\text { Average } \\
\text { observed } \\
\text { biomass } \\
\text { yield }\end{array}$ & $\begin{array}{c}\text { Average } \\
\text { IR } \\
\text { elasticity }\end{array}$ & $\begin{array}{l}\text { Average } \\
\text { extra } \\
\text { production } \\
\text { from } \\
\text { irrigation }\end{array}$ & $\begin{array}{c}\text { Average } \\
\text { biomass } \\
\text { price }\end{array}$ & $\begin{array}{l}\text { Average } \\
\text { gross } \\
\text { value per } \\
\text { acre } \\
\text { irrigated\# }\end{array}$ & $\begin{array}{l}\text { Average } \\
\text { acres } \\
\text { irrigated }\end{array}$ & $\begin{array}{c}\text { Average } \\
\text { total } \\
\text { gross } \\
\text { value of } \\
\text { irrigation } \\
\text { water }\end{array}$ \\
\hline State & $\begin{array}{c}\text { (metric } \\
\text { tons per } \\
\text { acre) }\end{array}$ & & $\begin{array}{c}\text { (metric } \\
\text { tons per } \\
\text { acre) }\end{array}$ & $\begin{array}{l}\text { (\$ per } \\
\text { metric ton } \\
\text { produced })\end{array}$ & (\$/acre) & $\begin{array}{c}\text { (million } \\
\text { acres) }\end{array}$ & $\begin{array}{c}\text { (million } \\
\$)\end{array}$ \\
\hline Colorado & 2.392 & 0.528 & 1.23 & 120.09 & $\begin{array}{l}133.23 \\
(15.92)\end{array}$ & 0.90 & 134.5 \\
\hline Kansas & 2.392 & 0.541 & 1.29 & 117.17 & $\begin{array}{l}136.48 \\
(15.67)\end{array}$ & 1.71 & 251.2 \\
\hline Nebraska & 2.919 & 0.480 & 1.34 & 118.65 & $\begin{array}{l}142.94 \\
(19.18)\end{array}$ & 5.09 & 825.9 \\
\hline N Mexico & 2.285 & 0.480 & 1.09 & 149.92 & $\begin{array}{l}147.14 \\
(19.13)\end{array}$ & 0.29 & 38.8 \\
\hline Oklahoma & 1.545 & 0.581 & 0.91 & 129.77 & $\begin{array}{l}104.57 \\
(11.02)\end{array}$ & 0.13 & 17.0 \\
\hline S Dakota & 1.398 & 0.627 & 0.88 & 118.71 & $\begin{array}{l}97.42 \\
(9.41)\end{array}$ & 0.01 & 0.7 \\
\hline Texas & 1.544 & 0.516 & 0.77 & 127.85 & $\begin{array}{c}85.74 \\
(10.78)\end{array}$ & 2.63 & 252.6 \\
\hline Wyoming & 1.815 & 0.493 & 0.89 & 124.66 & $\begin{array}{c}98.77 \\
(12.32)\end{array}$ & 0.21 & 21.9 \\
\hline HPA & 2.340 & 0.511 & 1.17 & 121.79 & $\begin{array}{c}125.2 \\
(15.84)\end{array}$ & 10.96 & 1542.6 \\
\hline
\end{tabular}

Note: \# numbers in parentheses are standard errors of this estimates obtained using the delta approach. 
Table 4. Estimated Annual Average Irrigation Water Value by State (3SLS+FE), 2007

\begin{tabular}{|c|c|c|c|c|c|c|c|}
\hline State & $\begin{array}{l}\text { Observed } \\
\text { biomass } \\
\text { yield }\end{array}$ & $\begin{array}{c}\text { IR } \\
\text { elasticity }\end{array}$ & $\begin{array}{c}\text { Extra } \\
\text { production } \\
\text { from irrigation }\end{array}$ & $\begin{array}{l}\text { Biomass } \\
\text { price }\end{array}$ & $\begin{array}{l}\text { Gross } \\
\text { value per } \\
\text { acre } \\
\text { irrigated\# }\end{array}$ & $\begin{array}{l}\text { Acres } \\
\text { irrigated }\end{array}$ & $\begin{array}{c}\text { Total } \\
\text { gross } \\
\text { value of } \\
\text { irrigation } \\
\text { water }\end{array}$ \\
\hline & $\begin{array}{l}\text { (metric } \\
\text { tons per } \\
\text { acre) }\end{array}$ & & $\begin{array}{c}\text { (metric tons } \\
\text { per acre) }\end{array}$ & $\begin{array}{l}\text { (\$ per } \\
\text { metric } \\
\text { ton } \\
\text { produced })\end{array}$ & (\$/acre) & $\begin{array}{l}\text { (million } \\
\text { acres) }\end{array}$ & $\begin{array}{c}\text { (million } \\
\$)\end{array}$ \\
\hline Colorado & 3.298 & 0.626 & 2.00 & 98.91 & $\begin{array}{l}196.02 \\
(19.29)\end{array}$ & 1.12 & 238.3 \\
\hline Kansas & 3.201 & 0.631 & 1.98 & 100.20 & $\begin{array}{l}197.15 \\
(19.06)\end{array}$ & 2.43 & 528.2 \\
\hline Nebraska & 4.371 & 0.563 & 2.34 & 102.26 & $\begin{array}{l}241.17 \\
(26.94)\end{array}$ & 7.60 & 2065.3 \\
\hline N Mexico & 3.435 & 0.596 & 1.90 & 110.35 & $\begin{array}{l}203.64 \\
(21.61)\end{array}$ & 0.27 & 46.6 \\
\hline Oklahoma & 2.244 & 0.698 & 1.55 & 100.07 & $\begin{array}{l}154.93 \\
(13.45)\end{array}$ & 0.13 & 28.8 \\
\hline S Dakota & 1.780 & 0.715 & 1.27 & 104.18 & $\begin{array}{l}133.15 \\
(11.16)\end{array}$ & 0.01 & 0.6 \\
\hline Texas & 2.089 & 0.613 & 1.26 & 113.14 & $\begin{array}{l}133.44 \\
(13.21)\end{array}$ & 2.90 & 397.0 \\
\hline Wyoming & 2.467 & 0.532 & 1.32 & 104.05 & $\begin{array}{l}131.61 \\
(14.66)\end{array}$ & 0.21 & 29.0 \\
\hline HPA & 3.337 & 0.601 & 1.91 & 104.26 & $\begin{array}{l}195.78 \\
(20.42)\end{array}$ & 14.67 & 3333.8 \\
\hline
\end{tabular}

Note: \# numbers in parentheses are standard errors of this estimates obtained using the delta approach. 


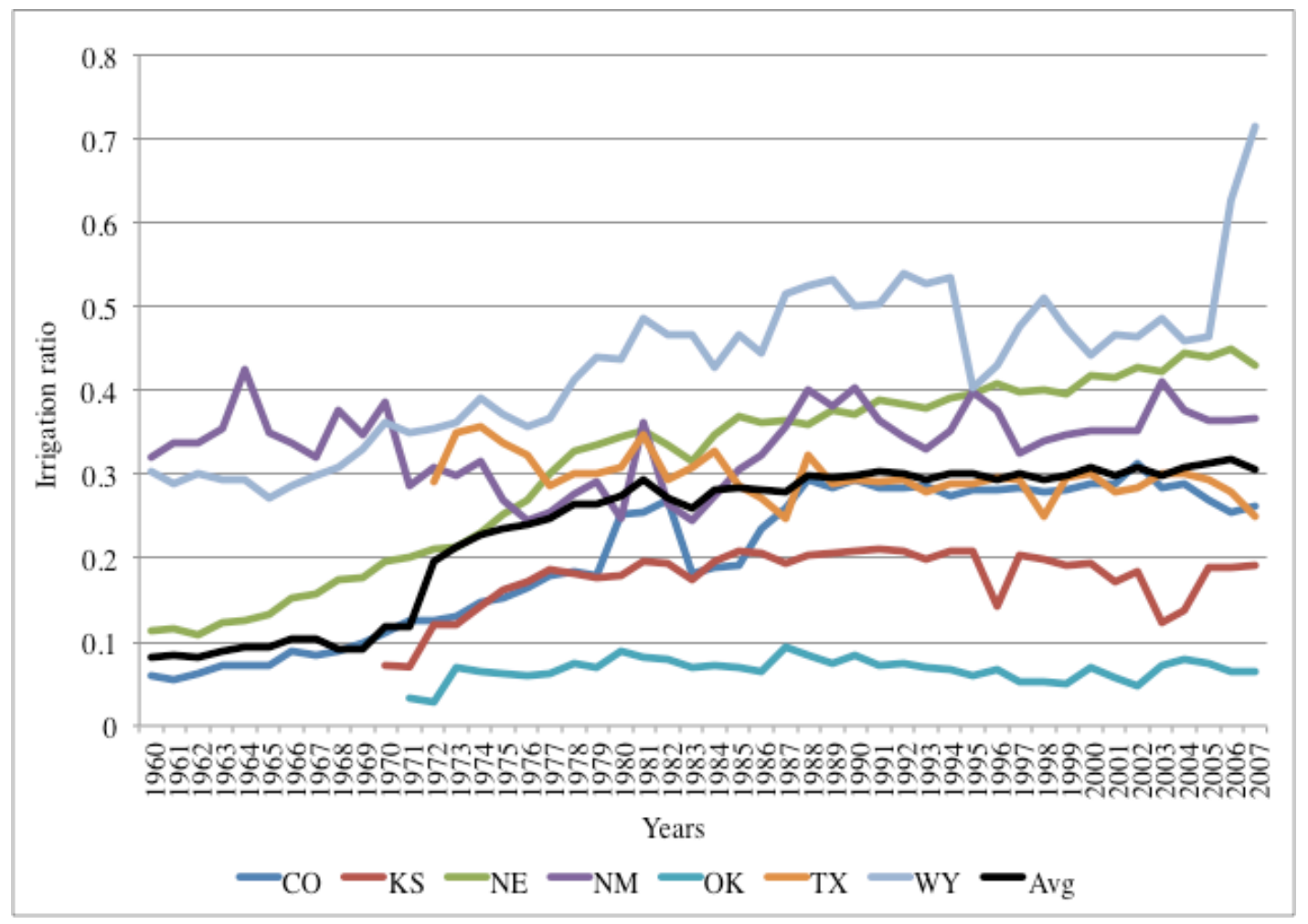

Figure 1. Irrigated land as a proportion of planted land in the HPA counties, 19602007 


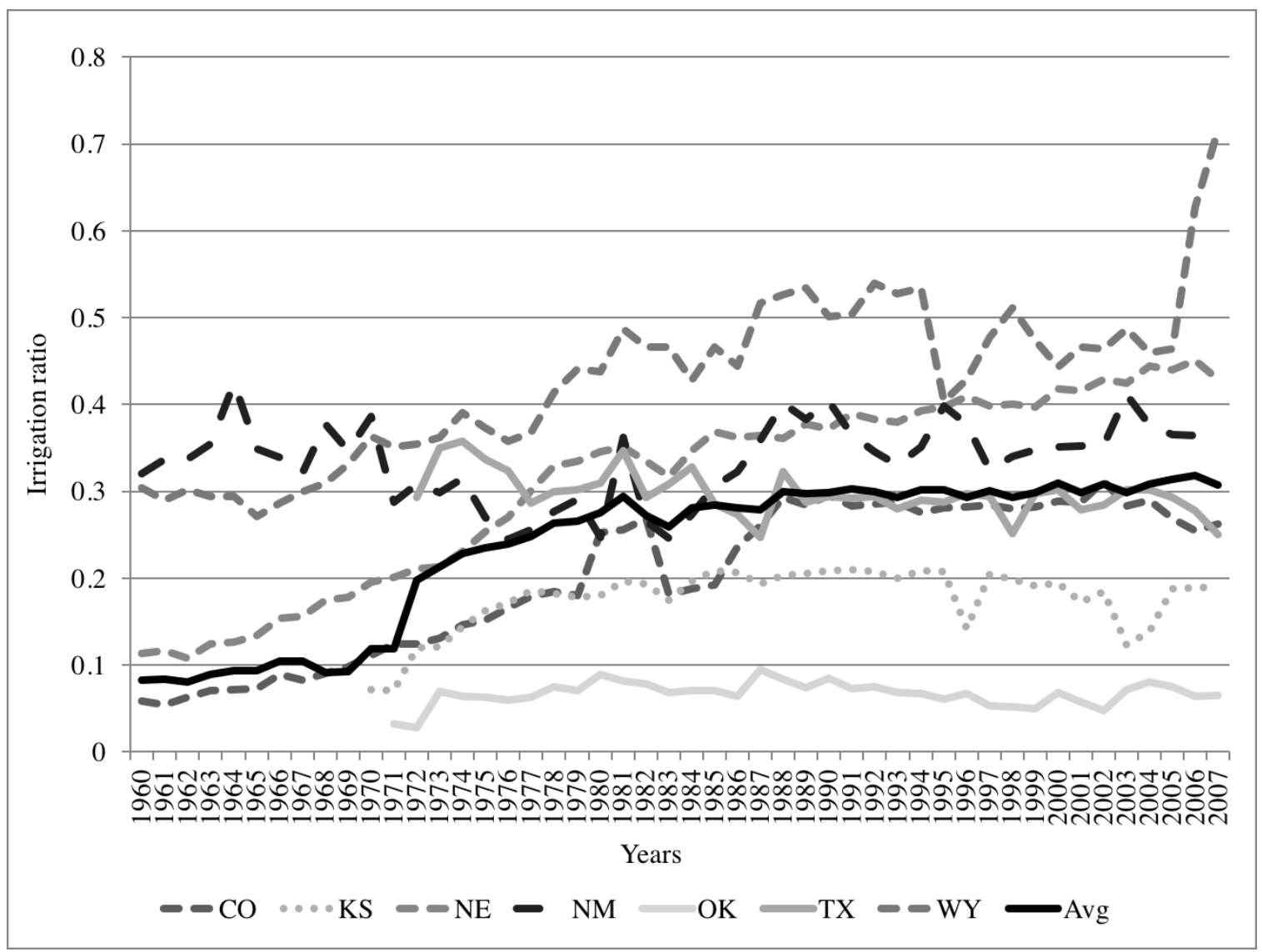

Figure 1. Irrigated land as a proportion of planted land in the HPA counties, 19602007 (print) 


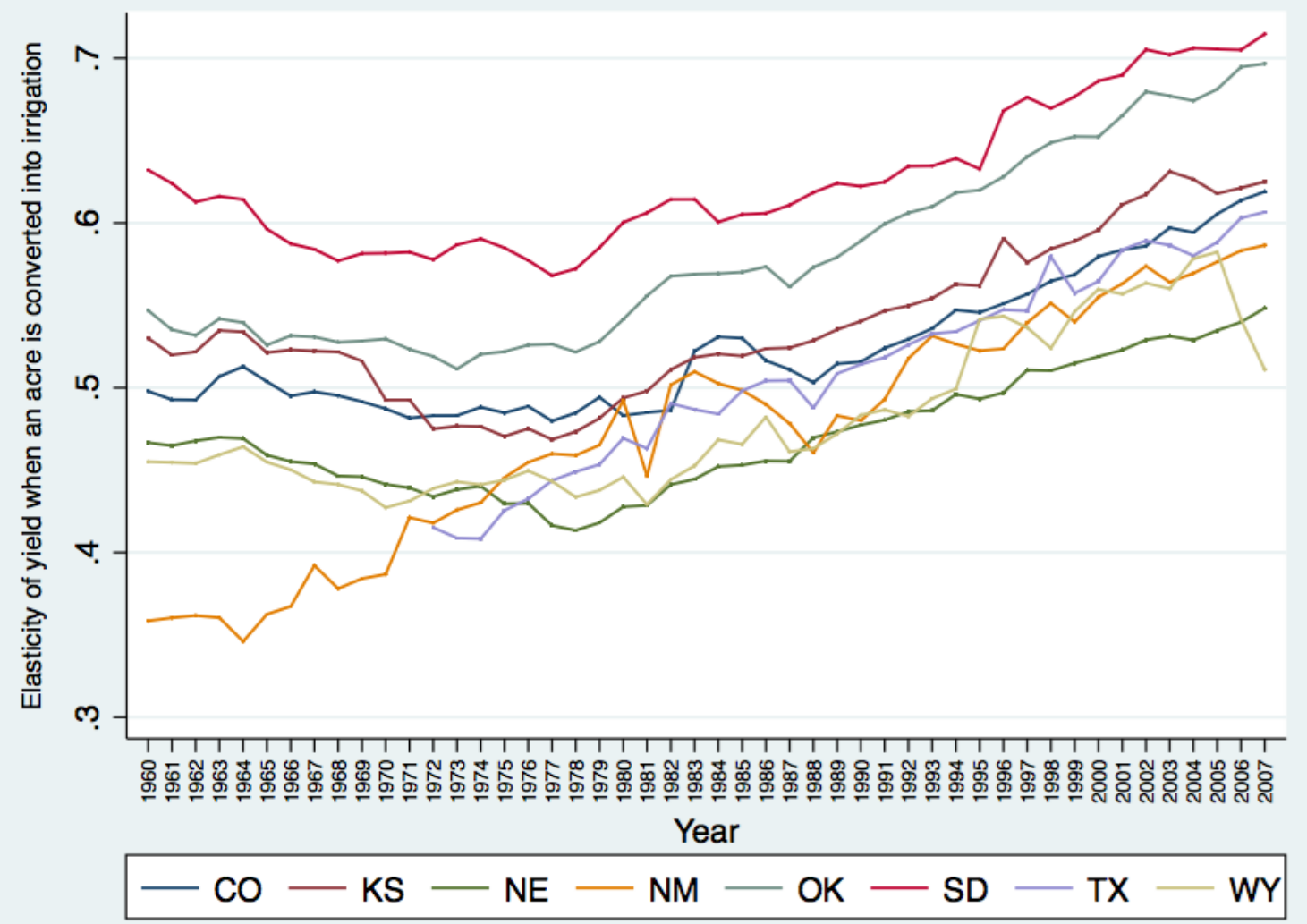

Figure 2. Evolution of the elasticity of yield response to irrigation by state, 3SLS+FE model, HPA counties, 1960-2007 


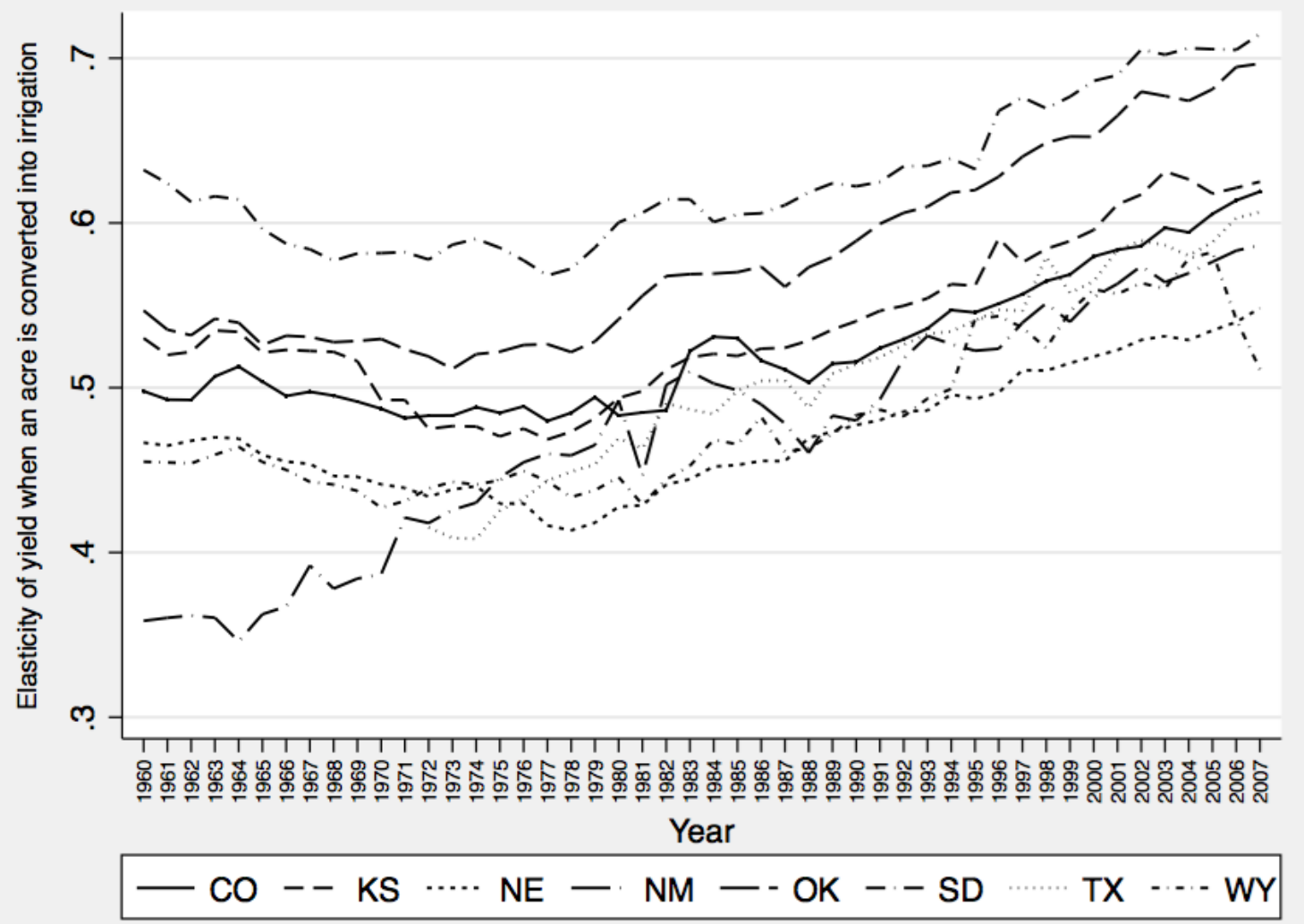

Figure 2. Evolution of the elasticity of yield response to irrigation by state, 3SLS+FE model, HPA counties, 1960-2007 (print) 


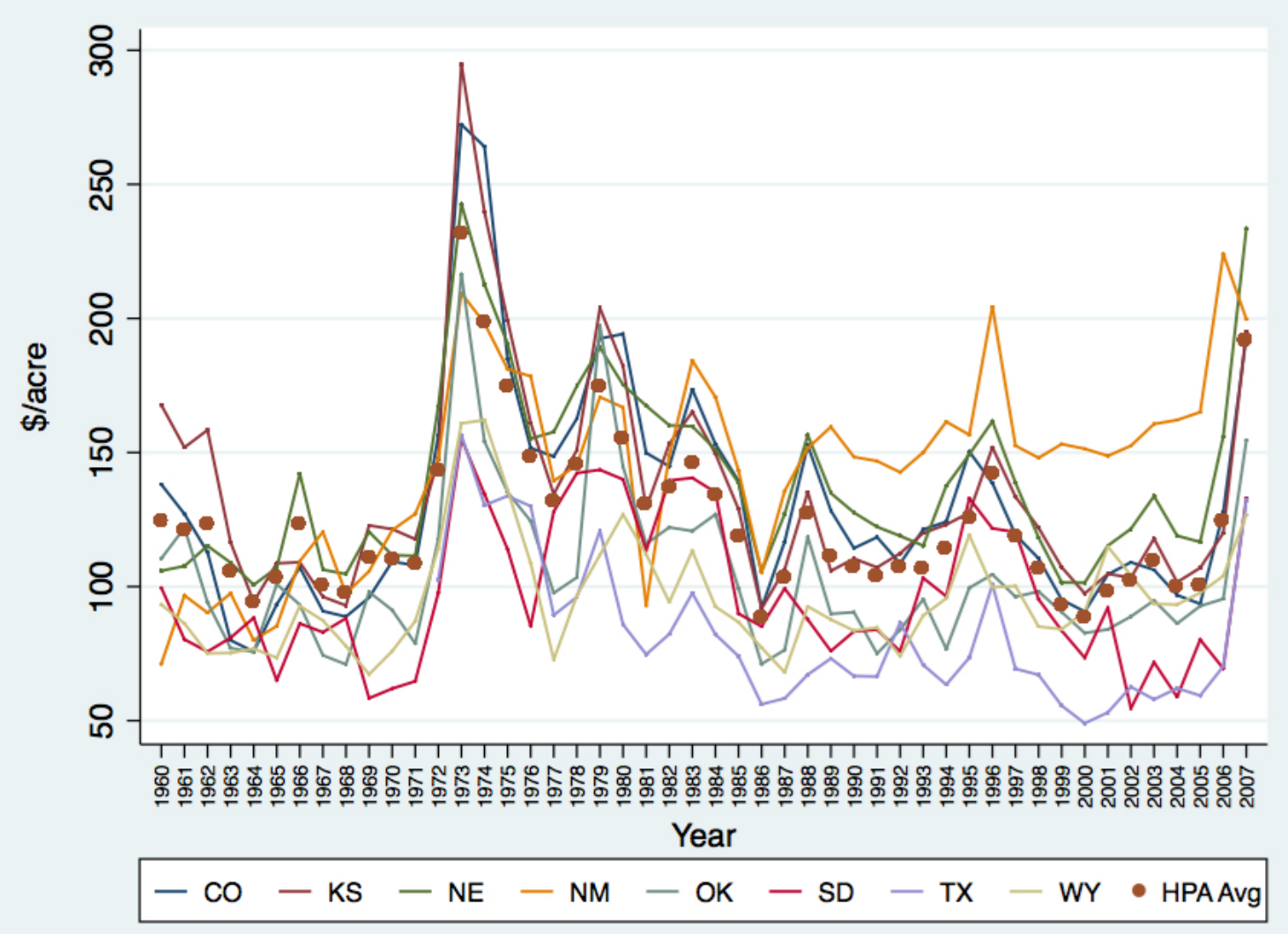

Figure 3. Agricultural value of irrigation water per acre by state, 3SLS+FE model (2007 dollars). 


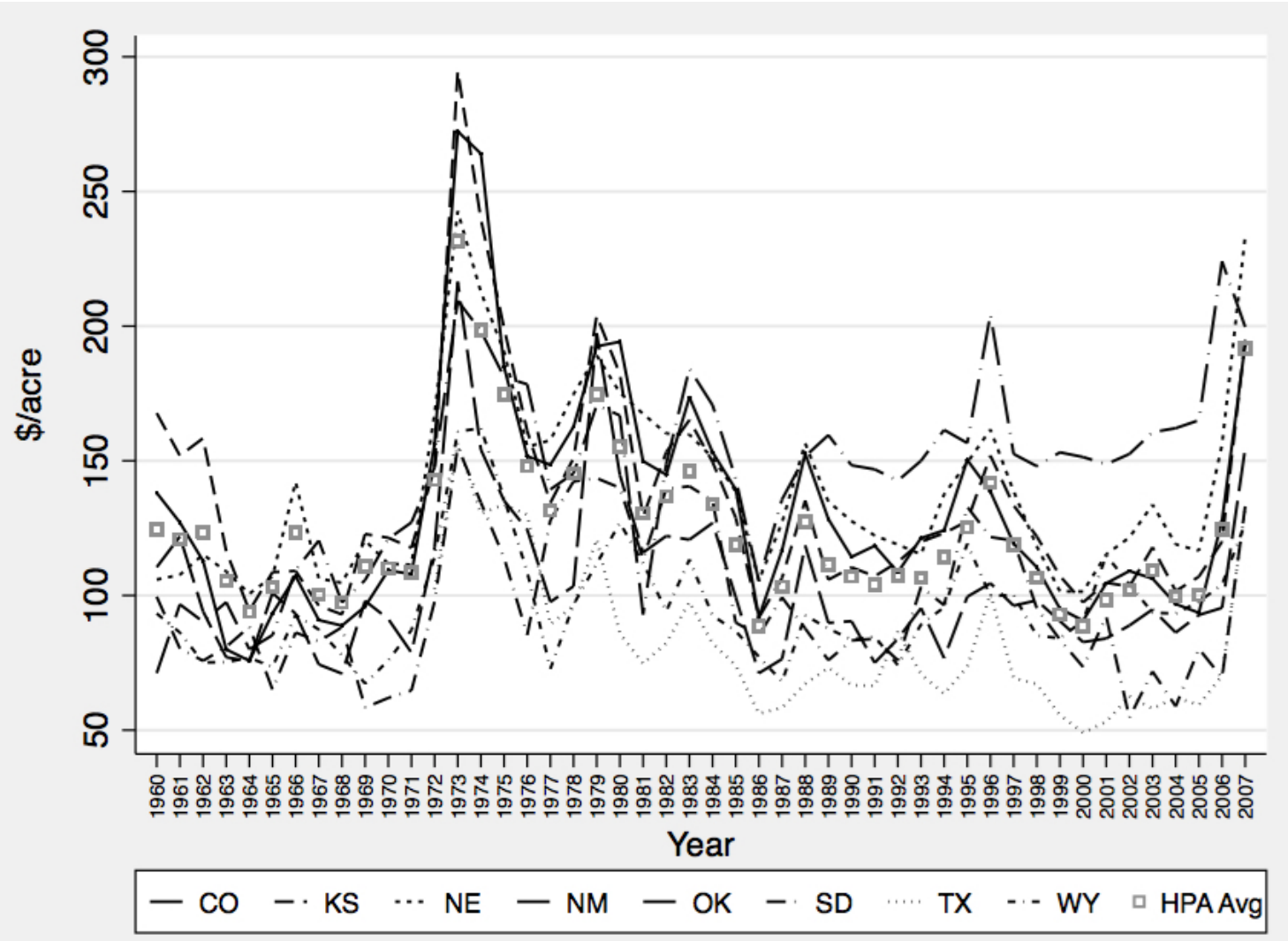

Figure 3. Agricultural value of irrigation water per acre by state, 3SLS+FE model, (2007 dollars). (print) 

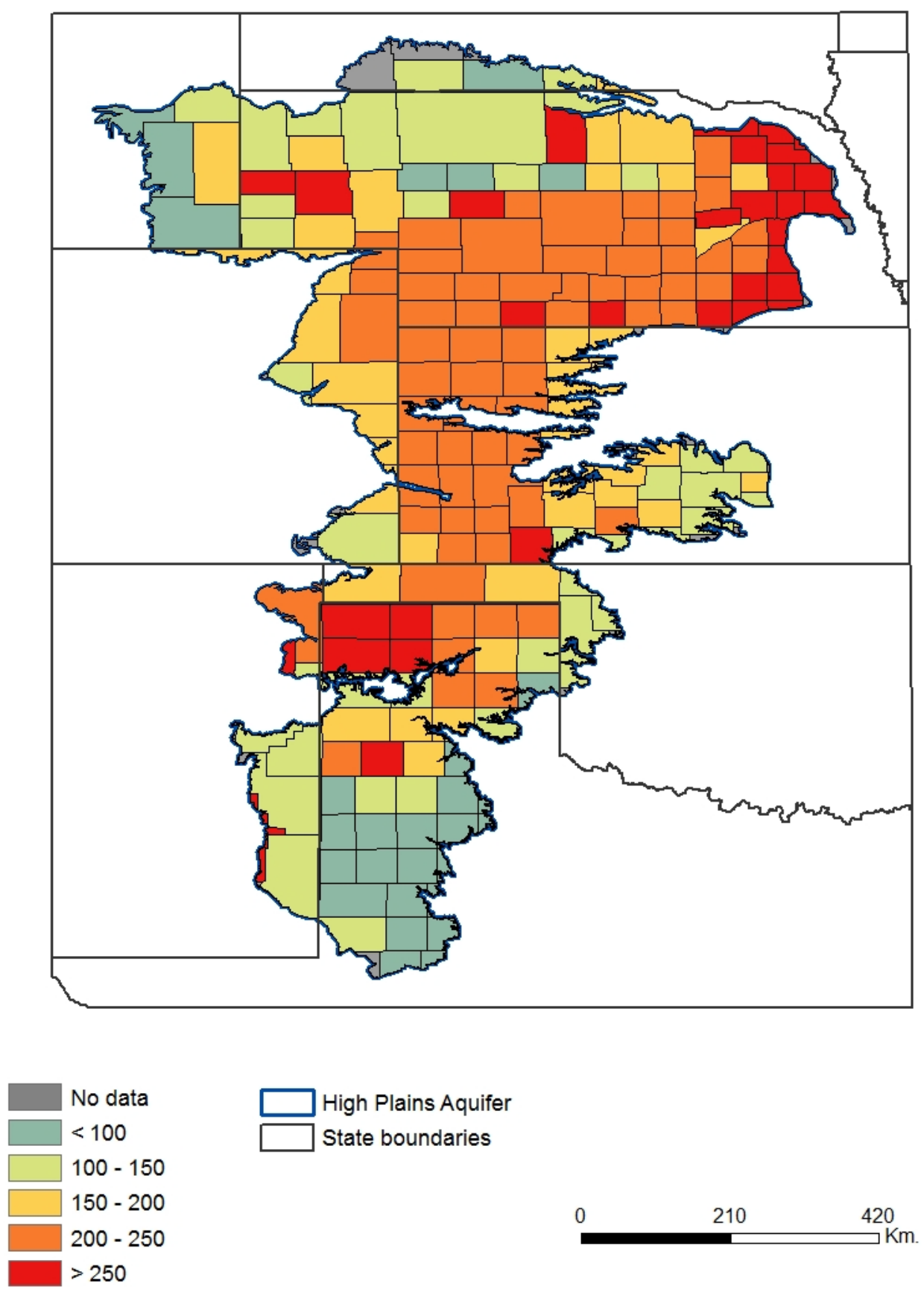

Figure 4. Estimated agricultural value of irrigation by county, 2007 


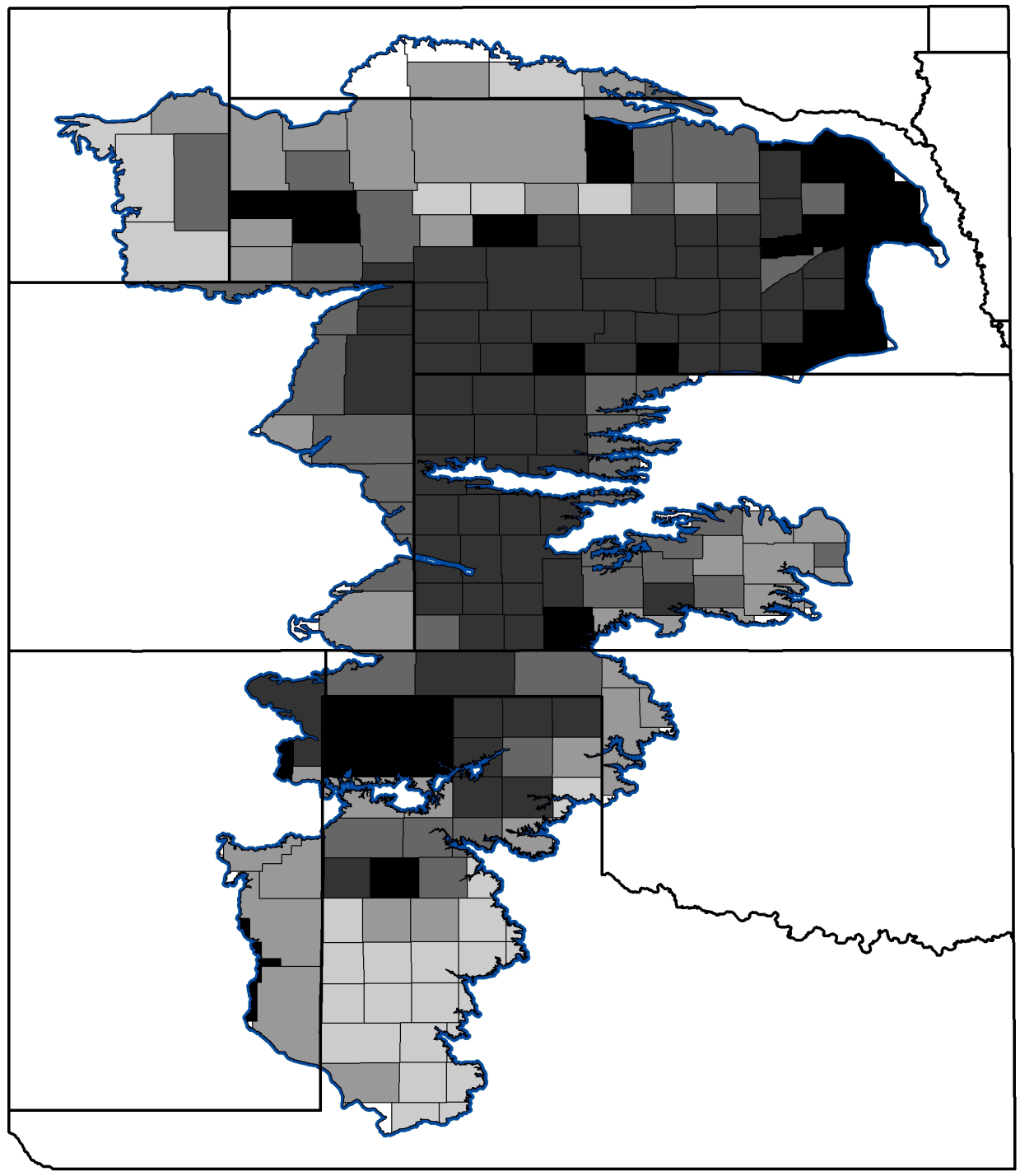

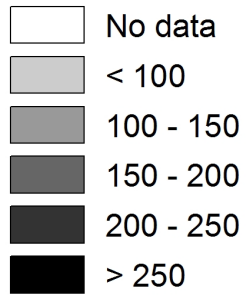

High Plains Aquifer State boundaries

Figure 4. Estimated agricultural value of irrigation by county 
i See Young and Loomis (2014) for a comprehensive treatment of methods used in groundwater valuation and early literature. Recent research includes Ding and Peterson (2012), Hendricks and Peterson (2012), Pfeiffer and Lin (2012, 2014a, 2014b), Palazzo and Brozović (2014), Ziolkowska (2015), Mieno and Brozović (2016).

ii Three of the 208 counties over the HPA are not used in the analysis because two counties in South Dakota did not have information and one in Texas had very few years of reported irrigation data.

iii The list of crops and their conversion coefficients are in the supplementary material Appendix 1, Table 2.

iv Fertilizer price index from http://www.ers.usda.gov/data-products/fertilizer-use-andprice.aspx.Upsw_5FEepw. Chemicals price index from USDA-NASS.

${ }^{\vee}$ Expected output prices approximated by an ARMA $(1,1)$ process.

vi Since the Translog production function includes second order terms that are cross products between exogenous and endogenous variables, there are 15 first-stage regressions (endogenous: fertilizer, chemicals, irrigation, and their second order terms in the translog yield function). There are 18 instruments: fertilizer price, chemicals price, predicted output prices, lagged fertilizer, lagged chemicals, lagged irrigation, squares and cross products between these lagged variables and with precipitation and time. F- tests for instruments in the first-stage regressions for each of the 15 endogenous variables as well as the Cragg-Donald F-tests for the logarithm of yields, share of fertilizer and share of chemicals equations fitted are in the Supplementary Material. Parameters from the 15 
first-stage regressions for the 3SLS + FE model and their statistics are also shown in the Supplementary Material.

vii Irrigation response from models that allowed for spatial effects other than fixed effects provided estimates within the range of results obtained in the three stage least square models in this article. Estimates obtained from alternative spatial model specifications can be found in García Suárez (2013). 